\title{
Glottic Cancer pT4a TNM Finding v7
}

National Cancer Institute

\section{Source}

National Cancer Institute. Glottic Cancer pT 4a TNM Finding v7. NCI Thesaurus. Code C89068.

Glottic cancer with moderately advanced local disease. Tumor invades through the outer cortex of the thyroid cartilage and/or invades tissues beyond the larynx (e.g., trachea, soft tissues of neck including deep extrinsic muscle of the tongue, strap muscles, thyroid, or esophagus). (from AJCC 7th Ed.) 